\title{
Mercury bio-extraction by fungus Coprinus comatus: a possible bioindicator and mycoremediator of polluted soils?
}

\author{
Jerzy Falandysz ${ }^{1}$
}

Received: 4 August 2015 / Accepted: 11 December 2015 / Published online: 26 December 2015

(C) The Author(s) 2015. This article is published with open access at Springerlink.com

\begin{abstract}
The Shaggy Ink Cap (Coprinus comatus), which is a common in wild in northern hemisphere was examined in field for potential to be used as possible bio-extractor of $\mathrm{Hg}$ from polluted grounds but also as possible bioindicator of urban soils (roadside, barren lands, lawns) pollution with $\mathrm{Hg}$. The contents of $\mathrm{Hg}$ in caps and stipes of C. comatus from the grounds examined in this study correlated positively with the levels of soil contamination. Analysis of sets of data available worldwide on $\mathrm{Hg}$ in C. comatus and soils beneathfruiting bodies showed on a positive correlation between degree of soil and mushroom contamination. Hence, C. comatus could be considered as a sensitive species and with bioindication and bioremediation potency for soils polluted with $\mathrm{Hg}$ in further studies. Young-fruiting bodies of C. comatus are edible and considered excellent if consumed soon after pick-up. Eating them when foraged from the urban places can provide to a consumer $\mathrm{Hg}$ at relatively high dose, while unresolved question is absorption rate of $\mathrm{Hg}$ compounds contained in ingested mushroom meal.
\end{abstract}

Keywords Foraging · Fungi · Mycoremediation · Shaggy Ink Cap

\section{Introduction}

Environmental pollution with heavy metals such as $\mathrm{Cd}, \mathrm{Hg}$, $\mathrm{Pb}$, and their accumulation in soils due to the industrial

Responsible editor: Elena Maestri

Jerzy Falandysz

jerzy.falandysz@ug.edu.pl

1 Laboratory of Environmental Chemistry and Ecotoxicology, Gdańsk University, 63 Wita Stwosza Str., PL 80-308 Gdańsk, Poland activities, urbanization, and traffic is an ongoing process, and various efforts are undertaken to effectively reduce and eliminate the sources as well as to restore degraded grounds (McGrath and Zhao 2003; Xu et al. 2015). One of the biological techniques of soil restoring discussed in scientific literature is mycoremediation using macrofungi (Gadd et al. 2012).

Macrofungi are well known for their ability to efficiently absorb various metallic elements and metalloids from the substrata and to sequester them in their fruiting bodies (Byrne and Tušek-Žnidarič 1990). Hence, fruiting bodies of edible and inedible mushrooms can be relatively rich in inorganic constituents, and data published on metals and minerals composition and content of macrofungi is much more when compared to that on their potential to bio-extract elements (Falandysz and Borovička 2013; Falandysz et al. 2001b; Tel et al. 2014).

For example, Agaricus campestris is good for sequestering $\mathrm{Ag}$ (Falandysz and Danisiewicz 1995); Agaricus macrosporus for Cd (García et al. 2005); Amanita muscaria for Cd, Cu, V, Hg (Lepp et al. 1987; Drewnowska et al. 2013); Boletus edulis for Cd, Cu, $\mathrm{Hg}$ (Falandysz et al. 2011; Frankowska et al. 2010); Macrolepiota procera for $\mathrm{Ag}, \mathrm{Cu}, \mathrm{Cd}, \mathrm{Hg}$ (Gucia et al. 2012a and 2012b); Laccaria amethistina and Laccaria vinaceoavellanea for As (Zhang et al. 2015); Paxillus involutus for $\mathrm{Cu}, \mathrm{Zn}$ (Brzostowski et al. 2011a, and 2011b); Suillus grevillei for $\mathrm{Ag}, \mathrm{Cd}, \mathrm{Hg}$ (Chudzyński and Falandysz 2008; Chudzyński et al. 2009); Xerocomus badius for Ag, Cd, Hg (Falandysz et al. 2012; Kojta et al. 2012; Mleczek et al. 2015); Xerocomus subtomentosus for Ag, Cd, Hg, (Chojnacka et al. 2012; Jarzyńska et al. 2012). Some mushrooms have also capacity to hyperaccumulate certain elements in flesh, e.g., Amanita strobiliformis and Amanita submembranacea for Ag (Borovička et al. 2007, 2010).

Fungi in a few original studies has been postulated or tested as biota more or less useful in process of removing or decreasing the content of the hazardous metallic elements from 
degraded soils or contaminated compost, e.g. with $\mathrm{Hg}$ and Pleurotus ostreatus (Bressa et al. 1998), Ag and Agaricus bisporus (Byrne and Tušek-Žnidarič 1990; Falandysz et al. 1994), Cd, Cu, Hg, Pb and Armillaria mellea, Polyporus squamosus, Polyporus suiphureus (Demirbaş 2002); Ca, $\mathrm{Cs}, \mathrm{K}, \mathrm{Na}$ and Pleurotus eryngii (BystrzejewskaPiotrowska et al. 2008), $\mathrm{Cu}$ by Oudemansiella radicata (Jiang et al. 2015), ${ }^{239} \mathrm{Pu}$ and ${ }^{241} \mathrm{Am}$ and P. ostreatus (Galanda et al. 2014), Ag, Pb, Th, U and several species of mushrooms for which accumulation of those metals in fruiting bodies apparently does not depend on total content and chemical fractionation of these metals in soils (Kubrová et al. 2014).

Nevertheless, practical solutions are lacking and fishing for most suitable species continues. Recently, it has been shown in a pot study that Coprinus comatus in presence of chelating agents such as ethylenediaminetetraacetic acid (EDTA) or nitrilotriacetate (NTA) very efficiently take-ups of $\mathrm{Cd}, \mathrm{Cu}$, and $\mathrm{Pb}$ from soil (Cen et al. 2012), and similar study with added chelators has been conducted for Tricholoma lobayense Heim (Wang et al. 2012). A potential for bio-extraction of $\mathrm{Pb}$ from low-polluted soils has been shown for Oudemansiella radicata (Zhang et al. 2012).

Mercury is a particular example of environmental and food toxicant because of high toxicity and biomagnification of methylmercury (MeHg) in food chains. Mercury, because is highly volatile could be emitted due to any high temperature process (e.g., combustion of biomass or waste, production of cement, metal ore refining). At the local or regional scale, soil can become a hot spot polluted with $\mathrm{Hg}$ because of fumes from the nonferrous metals producing facilities, use of the $\mathrm{Hg}$ compounds as the catalyst in an organic chemicals manufacturing, or an improper storage and disposal of the $\mathrm{Hg}$ containing materials, products, and wastes ( $\mathrm{Hu}$ and Cheng 2012). Hence, both identifications of current and forgotten places polluted with this element as well as development of remediation techniques are the actual needs.

As mentioned, an exceptional feature of mushrooms when compared to vascular plants is efficient accumulation by them of mercury (Cibulka et al. 1996), and some examples are available on bioconcentration of $\mathrm{Hg}$ by several species both the ectomycorrhizal and saprophytic mushrooms (Falandysz 2002; Falandysz et al. 2001a, 2002a, b, 2003a, b, c and 2014b; Krasińska and Falandysz 2015a, b; Melgar et al. 2009; Nasr and Arp 2011; Rieder et al. 2011). The rates of transfer (bioconcentration) of $\mathrm{Hg}$ sequestered in fruiting bodies by mushrooms depend on species and decrease with increasing soil/substratum $\mathrm{Hg}$ content because of limited natural capacity for accumulation (Bargagli and Baldi 1984; Falandysz et al. 2012; Falandysz and Drewnowska 2015a), while some species will tolerate highly polluted grounds because of cinnabar mining and can accumulate $\mathrm{Hg}$ at remarkably great concentration (Árvay et al. 2014). Also, mushrooms with deeper mycelia when emerged from red and yellow lateritic soils enriched with $\mathrm{Hg}$ in the mineral layer because of occurrence of the Circum-Pacific Mercuriferous Belt could accumulate $\mathrm{Hg}$ in fruiting bodies at highly elevated concentration (Falandysz et al. 2015a, b; Kojta et al. 2015; Wiejak et al. 2014).

Nevertheless, this is difficult to find in nature a such good example positive relationship, at local scale but exceptions probably happen if there is diversity of $\mathrm{Hg}$ concentration in soil substrate to a given species of mushroom. For example, when studding mercury $(\mathrm{Hg})$ - total $\mathrm{Hg}$ for some mushrooms and places, a good correlation has been found between soil (substrata) Hg and mushroom Hg for Macrolepiota procera (Falandysz and Chwir 1997). The same was for methylmercury $(\mathrm{MeHg})$ and a set of four samples (three individuals of Boletus (Xerocomus) badius - current name Imleria badia and one of Leccinum scabrum) form abandoned $\mathrm{Hg}$ mine (Fischer et al. 1995) but this was not exactly the same for inorganic $\mathrm{Hg}$.

A layer(s) in soil where mycelia lives and layer(s) in soil where $\mathrm{Hg}$ is contained and available matter. Deposition of airborne mercury from a long-range transport in pristine region of the Himalayan size Mountain Gongga (Minya Konka) in the eastern Tibetan plateau is the only explanation for elevated Hg content in the Gymnopus erythropus and Marasmius dryophilus, which both have shallow mycelia (Falandysz et al. 2014a). In a case of mushrooms that have deeper mycelia a diversification of $\mathrm{Hg}$ contents, as observed for several species of Leccinum and Boletus mushrooms from the Yunnan Province in China, could rather reflect the local/regional differences of $\mathrm{Hg}$ in the mineral layer of soil due to the geochemical anomalies but not because of fallout from the anthropogenic emissions from the beginning of the era of industrialization of the world (Falandysz et al. 2015a, b).

Coprinus comatus (O.F. Müll.) Pers. that is commonly named as Shaggy Ink Cap, Shaggy Mane, Shaggy Parasol, or Lawyer's Wing and is popular saprophytic mushroom in moderate climate, and its young-fruiting bodies are edible (Lassoe et al. 1996). This mushroom can be found emerging from the ground on the city lawns, abandoned grounds, parks, along the roads, and waste areas, and hence is rather rare example of edible wild mushroom that survives unhostile urban condition and can be picked-up both in the cities and in villager areas. This species is picked up by some consumers even if emerged at grounds in populated city. The C. comatus is also cultivated in China as food.

Aim of this study was to examine, if the Shaggy Ink Cap, which is a common in wild in northern hemisphere, has any potential to be used as possible bio-extractor of $\mathrm{Hg}$ from polluted grounds but also as possible bioindicator of urban soils (roadside, barren lands, lawns) pollution with Hg. Also, estimated was the possible intake rate of total mercury by consumers of $C$. comatus at the region investigated. Data available on $\mathrm{Hg}$ accumulated in C. comatus from Europe and Asia were summarized. 


\section{Materials and methods}

The specimens of fruiting bodies of $C$. comatus and topsoil $(0-10-\mathrm{cm}$ layer) samples beneath to them were collected at several sites from an area of the town of Kartuzy (14866 people) in Kaszuby region of the Pomerania land in the northern part of Poland in 2011 (Fig. 1; Table 1). Two sampling places assigned respectively with number 1 , and two other with number 2 (Fig. 1) were considered as of the similar character. Hence, mushrooms and soil samples collected at two places with number 1 were integrated to make composite samples, and the same was in the case of material collected at the places assigned with number 2 . The region of Kartuzy is surrounded by farmland, woodland and lakes, while apart from tourism in summer an industrial activity is little and restricted to small wood processing facilities and processing of crops.

A "young" (white) of edible quality fresh-fruiting bodies, after clean up with a plastic knife from any visible plant vegetation and soil substrate debris and bottom part of the stipe was cut off, was separated into two parts - cap and stipe. Next, they were in situ sliced and dried (initially in ambient temperature for $0.5-2 \mathrm{~h}$ ) and further were placed into plastic basket of an electrically heated commercial dryers (dehydrator for mushrooms, fruits, vegetables and herbs; model: MSG-01; MPM Product, Milanówek, Poland) and dried at $65{ }^{\circ} \mathrm{C}$ to constant mass. Dried mushrooms parts were respectively pooled and pulverized in a porcelain mortar and kept in brand new sealed polyethylene bags under dry conditions. The soils (0-10-cm layer) and litter samples free of any visible organisms, small stones, sticks, and leaves were air dried at room temperature for several weeks under clean condition. Next, the
Table 1 Summary of details on materials Coprinus comatus

\begin{tabular}{llll}
\hline \multirow{2}{*}{$\begin{array}{l}\text { Place } \\
\text { ID }\end{array}$} & Name of the place & \multicolumn{2}{l}{ Type of material } \\
\cline { 3 - 4 } & & Fungus & Soil \\
\hline 1 & Kartuzy, Wzgórze Wolności/ Prokowska Str. & $3(13)^{\mathrm{b}}$ & 3 \\
2 & Kartuzy, Sambora Str./3 Maja Str. & $3(13)$ & 3 \\
3 & Kartuzy, Weglowa Str. & $3(15)$ & 3 \\
4 & Kartuzy, Majkowskiego Str. (center of town) & $3(13)$ & 3 \\
5 & Kartuzy, Majkowskiego Str. (northern edge) & $3(13)$ & 3 \\
6 & Kczewo village & $3(15)$ & 3 \\
7 & Pępowo village & $3(13)$ & 3 \\
8 & Leźno village & $3(13)$ & 3 \\
\hline
\end{tabular}

Samples and total number of fruiting bodies per place (in parentheses)

${ }^{a}$ numeration of the sampling place (see Figs 1 and 2)

${ }^{\mathrm{b}}$ number of pooled

soil samples were sieved through a pore size of 2-mm plastic sieve and sealed in brand new polyethylene bags and kept under dry and clean condition. Mushrooms and soil samples were pooled, respectively (Table 1).

Mercury was determined using a direct sample matrices thermal decomposition and cold-vapor atomic absorption spectroscopy (CV-AAS; Mercury analyzer type MA-2000, Nippon Instruments Corporation, Takatsuki, Japan) (Jarzyńska and Falandysz 2011; Nnorom et al. 2013). The accuracy of the method was evaluated and further controlled by examination of the fungal-certified reference materials (CRM) and reagent blanks (both with every set of 5 fungal or soil samples). The CRM fungal material used were driedfruiting bodies of Cow Bolete (Suillus bovinus; code: CS-M-

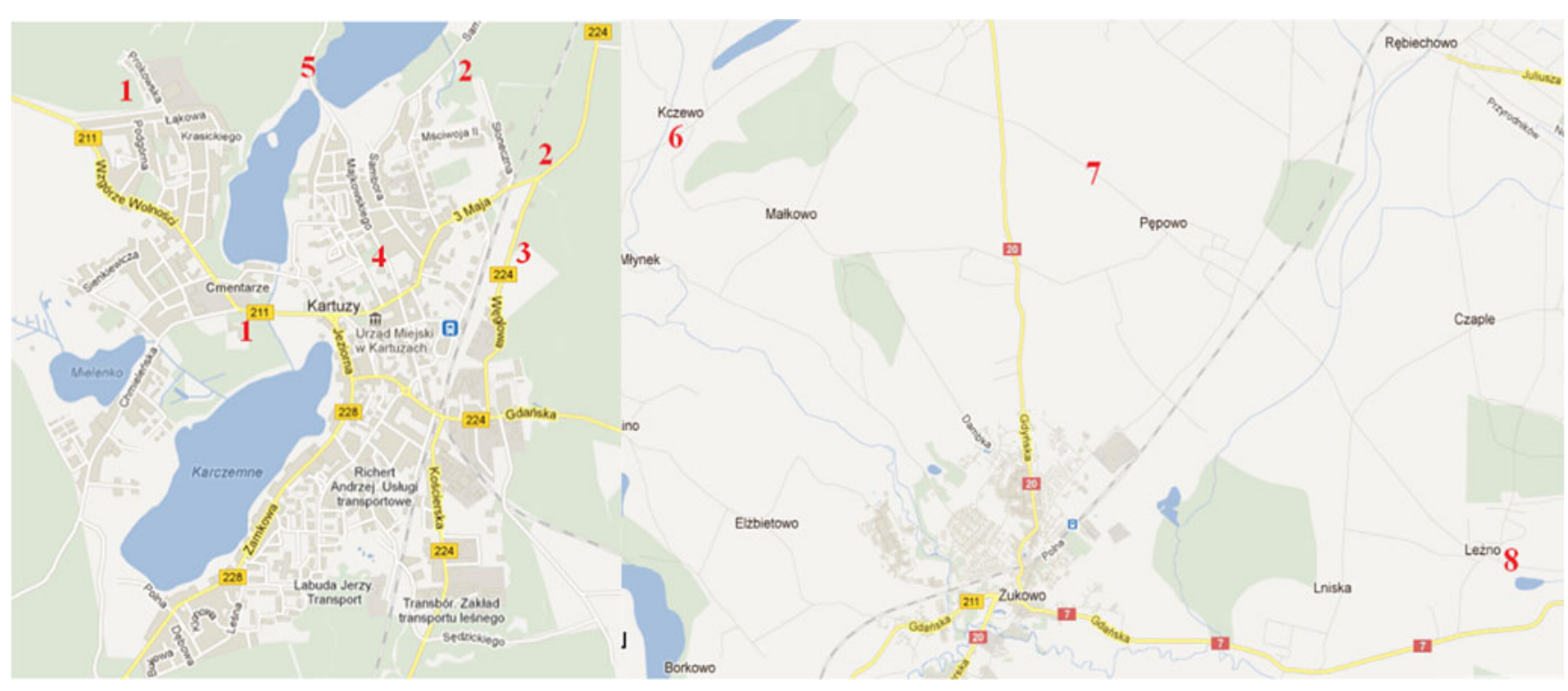

Fig. 1 Localization of the sampling places of C. comatus and soils in the town of Kartuzy $\left(54^{\circ} 20^{\prime} 06^{\prime \prime} \mathrm{N}\right.$ and $\left.18^{\circ} 12^{\prime} 05^{\prime \prime} \mathrm{E} ; 1-5\right)$ and elsewhere:

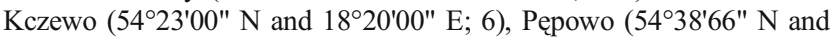

$\left.18^{\circ} 40^{\prime} 23^{\prime \prime} \mathrm{E} ; 7\right)$ and Leźno (54²1 $1^{\prime \prime} \mathrm{N}$ and $\left.18^{\circ} 26^{\prime} 0^{\prime \prime} \mathrm{E} ; 8\right)$ in Pomerania land in northern part of Poland (Google maps; color figure available in online version) 
1) and the Basma 5 tobacco leaves code: INCT-OBTL-5, both produced by the Institute of Nuclear Technology and Chemistry (ICHTJ), Warsaw, Poland). The content of $\mathrm{Hg}$ in CS-M-1 declared by the producer is $0.174 \pm 0.018-\mathrm{mg} \mathrm{kg}^{-1}$ dry matter $(\mathrm{dm})$, while our measurements obtained in separate trials showed $0.168 \pm 0.009 \mathrm{mg} \mathrm{kg}^{-1} \mathrm{dm}(n=5)$. Declared content of $\mathrm{Hg}$ in INCT-OBTL-5 is $0.021 \pm 0.001-\mathrm{mg} \mathrm{kg}^{-1}$ $\mathrm{dm}$, and our result showed $0.020 \pm 0.006-\mathrm{mg} \mathrm{kg}^{-1} \mathrm{dm}$ $(n=5)$. For mushrooms and the soil substrates, the limit of detection was $0.005-\mathrm{mg} \mathrm{kg}^{-1} \mathrm{dm}$, and the quantification limit was $0.0015-\mathrm{mg} \mathrm{kg}^{-1} \mathrm{dm}$. One blank sample and one certified reference material sample were examined with each set of 3-10 samples studied.

Intake rate of total mercury was estimated based on median the values of mercury concentrations noted in fruiting bodies, possible intake rates of mushroom, and a provisionally tolerable intake limits of element to adult human.

The computer software Statistica, version 10.0 (Statsoft Polska, Kraków, Poland), was used for statistical analysis of data and for graphical presentation of the results of twodimensional multiple scatter plot relationships between the variables.

\section{Results and discussion}

The Shaggy Ink Cap seems to be a sensitive boindicator of urban soils pollution with $\mathrm{Hg}$ that is efficiently sequestered by this species in fruiting bodies - both caps and stipes (Table 2). The median values of $\mathrm{BCF}$ from the stand where topsoil showed $\mathrm{Hg}$ at $0.13-\mathrm{mg} \mathrm{kg}^{-1} \mathrm{dm}$ (no 3, Fig. 1; Table 1) reached up to 73 for caps and 30 for stipes. Also, $\mathrm{Hg}$ content of fruiting bodies from that stand was high and median value was 9.2$\mathrm{mg} \mathrm{kg}{ }^{-1} \mathrm{dm}$ in caps and $5.2-\mathrm{mg} \mathrm{kg}^{-1} \mathrm{dm}$ in stipes, An elevated content of $\mathrm{Hg}$ in topsoil and hence also in flesh of mushrooms at the stand no 3 could be explained by character of the ground usage there, where a scrap-heap and recycling company is active from a year. At two other places in Kartuzy (nos. 2 and 4, Fig. 1; Table 1), the median values of $\mathrm{Hg}$ in caps were between 2.5 and $3.0-\mathrm{mg} \mathrm{kg}^{-1} \mathrm{dm}$ (Table 2), which are values within a range of the concentrations determined in C. comatus from several urban places in Europe (Table 3). At the places west (no 1) and north (no 5) of the center of the town (Fig. 1)fruiting bodies of $C$. comatus were less contaminated, while much less were the mushrooms and soil collected in outskirts of two villages east of the town (nos. 6 and 7). At the Leźno
Table 2 Total mercury concentrations in caps and stipes of Coprinus comatus and beneath soil ( $\left.\mathrm{mg} \mathrm{kg}^{-1} \mathrm{dm}\right)$, the values of $\mathrm{Hg}$ caps to stipes concentration quotient $\left(\mathrm{Q}_{\mathrm{C} / \mathrm{S}}\right)$, and bioconcentration factor $(\mathrm{BCF})$ values

\begin{tabular}{|c|c|c|c|c|c|c|}
\hline \multirow[t]{2}{*}{ Place ID } & \multicolumn{2}{|c|}{$\mathrm{Hg}$ in mushrooms } & \multirow[t]{2}{*}{$\mathrm{Q}_{\mathrm{C} / \mathrm{S}}$} & \multirow[t]{2}{*}{ Hg Soil } & \multirow[t]{2}{*}{$\mathrm{BCF}_{\mathrm{c}}$} & \multirow[t]{2}{*}{$\mathrm{BCF}_{\mathrm{s}}$} \\
\hline & Caps & Stipes & & & & \\
\hline \multirow[t]{3}{*}{1} & $0.88 \pm 0.26$ & $0.39 \pm 0.90$ & $1.7 \pm 0.5$ & 0.077 & $12 \pm 3$ & $7.5 \pm 4.5$ \\
\hline & $(0.59-1.1)$ & $(0.29-0.96)$ & $(1.1-2.1)$ & $(0.068-0.083)$ & $(7.8-14)$ & $(3.8-13)$ \\
\hline & 0.98 & 0.47 & 2.0 & & 13 & 6.2 \\
\hline \multirow[t]{3}{*}{2} & $2.1 \pm 1.1$ & $1.1 \pm 0.6$ & $2.0 \pm 0.1$ & $0.04^{\mathrm{a}}$ & $52 \pm 27$ & $27 \pm 15$ \\
\hline & $(0.89-3.0)$ & $(0.42-1.6)$ & $(1.9-2.0)$ & & $(22-62)$ & $(22-74)$ \\
\hline & 2.5 & 1.1 & 2.0 & & 62 & 30 \\
\hline \multirow[t]{3}{*}{3} & $9.3 \pm 0.5$ & $5.5 \pm 0.7$ & $1.7 \pm 0.1$ & $0.13^{\mathrm{a}}$ & $74 \pm 4$ & $43 \pm 5$ \\
\hline & $(8.4-10)$ & $(5.0-6.3)$ & $(1.6-1.8)$ & & $(70-78)$ & $(39-50)$ \\
\hline & 9.2 & 5.2 & 1.7 & & 73 & 30 \\
\hline \multirow[t]{3}{*}{4} & $2.4 \pm 1.6$ & $1.3 \pm 0.8$ & $1.7 \pm 0.5$ & $0.034^{\mathrm{a}}$ & $70 \pm 46$ & $38 \pm 23$ \\
\hline & $(0.58-3.6)$ & $(0.47-2.1)$ & $(1.2-2.2)$ & & $(17-100)$ & $(14-60)$ \\
\hline & 3.0 & 1.4 & 1.7 & & 88 & 30 \\
\hline \multirow[t]{3}{*}{5} & $0.79 \pm 0.46$ & $0.34 \pm 0.21$ & $2.3 \pm 0.2$ & $0.025^{\mathrm{a}}$ & $31 \pm 18$ & $14 \pm 8$ \\
\hline & $(0.35-1.3)$ & $(0.14-0.56)$ & $(2.2-2.5)$ & & $(14-50)$ & $(5.6-22)$ \\
\hline & 0.75 & 0.33 & 2.3 & & 30 & 13 \\
\hline \multirow[t]{3}{*}{6} & $0.25 \pm 0.02$ & $0.12 \pm 0.02$ & $2.3 \pm 0.2$ & $0.026^{\mathrm{a}}$ & $9.5 \pm 0.8$ & $4.8 \pm 0.7$ \\
\hline & $(0.24-0.28)$ & $(0.11-0.15)$ & $(4.3-5.6)$ & & $(8.9-10)$ & $(5.6-22)$ \\
\hline & 0.24 & 0.12 & 1.9 & & 9.2 & 13 \\
\hline \multirow[t]{3}{*}{7} & $0.61 \pm 0.08$ & $0.35 \pm 0.03$ & $1.8 \pm 0.4$ & $0.024^{\mathrm{a}}$ & $26 \pm 3$ & $15 \pm 1$ \\
\hline & $(0.54-0.70)$ & $(0.32-0.38)$ & $(1.5-2.2)$ & & $(23-29)$ & $(13-16)$ \\
\hline & 0.61 & 0.35 & 1.6 & & 25 & 15 \\
\hline \multirow[t]{3}{*}{8} & $1.3 \pm 0.2$ & $0.63 \pm 0.15$ & $2.2 \pm 0.2$ & $0.043^{\mathrm{a}}$ & $31 \pm 5$ & $15 \pm 4$ \\
\hline & $(1.2-1.6)$ & $(0.49-0.79)$ & $(2.0-2.4)$ & & $(27-36)$ & $(11-18)$ \\
\hline & 1.3 & 0.62 & 2.1 & & 30 & 14 \\
\hline
\end{tabular}

${ }^{\text {a }}$ pooled samples for soil 
Table 3 Summary of data on total mercury concentrations in C. comatus and beneath soil, bioconcentration factor (BCF), and cap to stipe $\mathrm{Hg}$ content ration quotients $\left(\mathrm{Q}_{\mathrm{C} / \mathrm{S}}\right)$

\begin{tabular}{|c|c|c|c|c|}
\hline \multirow[t]{2}{*}{ Information } & \multicolumn{2}{|l|}{$\mathrm{Hg} \mathrm{mg} \mathrm{kg} \mathrm{dm}{ }^{-1}$} & \multirow[t]{2}{*}{$\mathrm{BCF}$} & \multirow[t]{2}{*}{ Reference } \\
\hline & Mushroom & Soil & & \\
\hline Norway, background & $1.7 / 0.85$ (cap/stipe) & & & Allen and Steinnes 1978 \\
\hline Finland $(n=2)^{\#}$ & $5.6(1.5-9.8)$ & & & Laaksovirta and Lodenius 1979 \\
\hline Finland, rural $(n=3)$ & $2.7(2.5-2.9)$ & & & Kuusi et al. 1981 \\
\hline Finland, urban $(n=37)$ & $4.7(0.68-17)$ & & & Kuusi et al. 1981 \\
\hline Finland, urban $(n=55)$ & $3.8(1.4-10)$ & & & Lodenius et al. 1981 \\
\hline Finland, lead processing area $(n=2)$ & $2.1(0.6-3.5)$ & & & Liukkonen-Lilja et al. 1983 \\
\hline Finland $(n=1)$ & 6.7 & & & Kojo and Lodenius 1989 \\
\hline Germany $(n=6)$ & $1.2(0.4-2.2)$ & & & Seeger and Nützel 1976 \\
\hline Germany, $\mathrm{Hg}$ mining area $(n=2)$ & 144 & 83 & 1.7 & Fischer et al. 1995 \\
\hline Switzerland $(n=1)$ & 2.8 & & & Stijve and Roschnik 1974 \\
\hline Switzerland $(n=4)$ & $3.3(0.57-8.0)$ & & & Quinche and Dvorak 1975 \\
\hline Switzerland $(n=7)$ & $3.1(0.51-5.6)$ & & & Quinche 1976 \\
\hline Switzerland $(n=17)$ & $2.5^{\mathrm{a}}(0.40-13)$ & & & Quinche 1992 \\
\hline Slovenia $(n=1)$ & 2.1 & 0.22 & 9.5 & Byrne et al. 1976 \\
\hline Croatia, eastern $(n=1)$ & 1.4 & & & Grgić et al. 1992 \\
\hline \multirow[t]{2}{*}{ Spain, Lugo $(n=10)$} & $2.6 \pm 1.3(\mathrm{H})$ & & 144 & Melgar et al. 2009 \\
\hline & $2.3 \pm 1.2(\mathrm{RFB})$ & & 115 & \\
\hline Italy, Mt. Amiata; $\mathrm{HgS}$ mine $(n=1)$ & 23 & 210 & 0.11 & Bargagli and Baldi 1984 \\
\hline Italy, Reggio Emilia & $0.78(0.42-1.1)^{\mathrm{a}}$ & & & Cocchi et al. 2006 \\
\hline China, Guangdong $(n=7)$ & $0.04(0.01-0.18)$ & & & Shen and Yu 2008 \\
\hline
\end{tabular}

$H$ hymenophore, $R F B$ rest of fruit body

${ }^{a}$ number of fruit bodies, $95 \%$ confidence interval place that is subjected for an intense road traffic, both topsoil and mushrooms showed an intermediate $\mathrm{Hg}$ content (Table 2). The geochemical background value of $\mathrm{Hg}$ (total $\mathrm{Hg}$ ) suggested for soils of Poland is $0.05-\mathrm{mg} \mathrm{kg}^{-1} \mathrm{dm}$ (PIG 2013), while the forest soils did contain in a top $0-10-\mathrm{cm}$ layer much less of $\mathrm{Hg}$ than $0.05-\mathrm{mg} \mathrm{kg}^{-1} \mathrm{dm}$ (Drewnowska et al. 2012 and 2014; Drewnowska and Falandysz 2015). In view of those figures, the soil sampled in the town of Kartuzy as well as other places (Fig. 1) can be considered as more or less contaminated with $\mathrm{Hg}$ from the anthropogenic emissions.
Fig. 2 Relationships between $\mathrm{Hg}$ content in the caps and stipes of Coprinus comatus and $\mathrm{Hg}$ in soil substratum (for caps: $\mathrm{y}=-1.2933+70.1161 * \mathrm{x}$; $r=0.87 ; p<0.005 ; r^{2}=0.75$; $p=0.0004$; for stipes: $\mathrm{y}=-0.8774+41.9787 * \mathrm{x}$; $r=0.87 ; p<0.005 ; r^{2}=0.75$ ) for locations examined

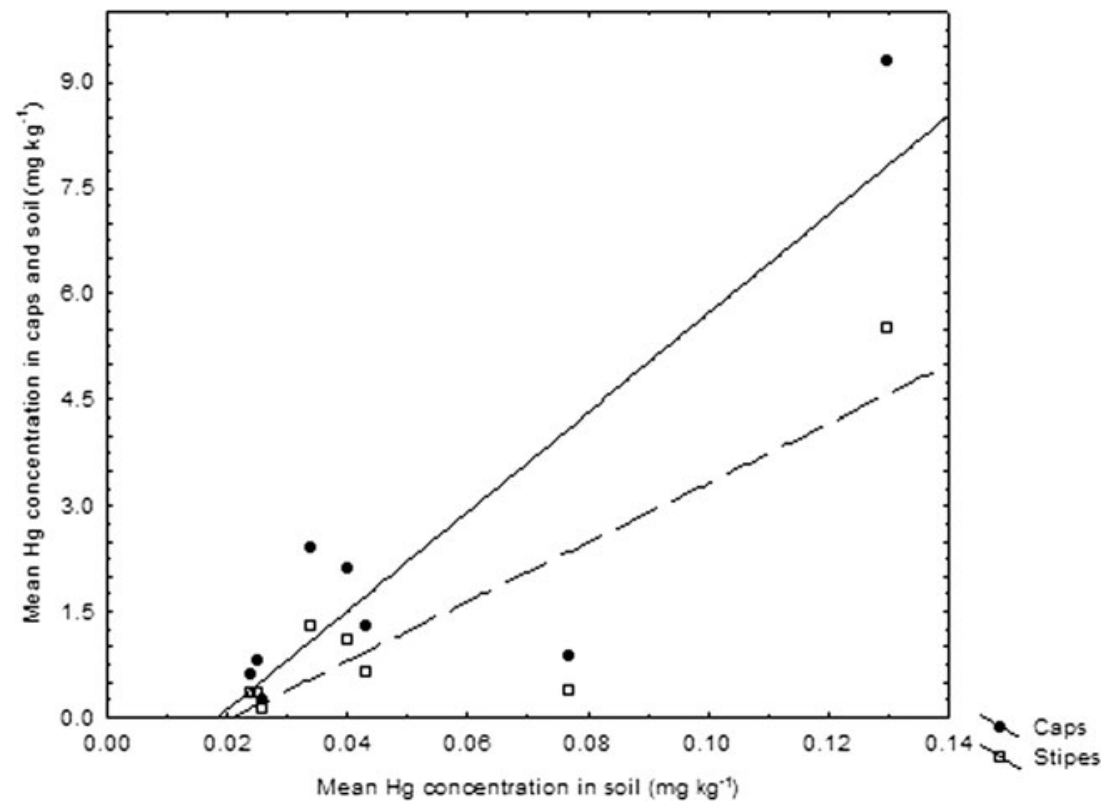


The contents of $\mathrm{Hg}$ in caps and stipes of C. comatus in this study correlated positively with the levels of soil contamination (Fig. 2). Earlier studies showed that C. comatus has a potential to accumulate mercury in fruiting bodies, e.g., for specimens from the cinnabar $(\mathrm{HgS})$ mining place in Germany with $\mathrm{Hg}$ in soil at $83-\mathrm{mg} \mathrm{kg}^{-1} \mathrm{dm}$, the content of $\mathrm{Hg}$ in two fruiting bodies was at 144-mg kg${ }^{-1} \mathrm{dm}$, while for cinnabar mining place in Italy with $\mathrm{Hg}$ in soil at $210-\mathrm{mg} \mathrm{kg}^{-1} \mathrm{dm}$, the content of $\mathrm{Hg}$ in a single fruiting body was much less, i.e., at $23-\mathrm{mg} \mathrm{kg}^{-1} \mathrm{dm}$. Also high was $\mathrm{Hg}$ content in $C$. comatus emerged at the urbanized places in Finland, which showed up to $17-\mathrm{mg} \mathrm{kg}^{-1} \mathrm{dm}$ (Table 3). In one study, the C. comatus, when compared to inorganic $\mathrm{Hg}$ has much better potential for bioconcentration of $\mathrm{MeHg}$ with a value of BCF reaching 198 (Fischer et al. 1995). Analysis of all sets of data available on $\mathrm{Hg}$ in C. comatus and soils (Tables 2 and 3) beneath fruiting bodies showed on a positive correlation between degree of soil and mushroom contamination. Hence, C. comatus can be considered as a sensitive species and with bioindication potency for soils polluted with $\mathrm{Hg}$.

As mentioned in the introductory section, young fruiting bodies of $C$. comatus are edible and considered excellent if consumed soon after pick-up, while kept in ambient temperature for longer period undergo auto digestion. Given data showed in Tables 2 and 3, the specimens of $C$. comatus emerged in urban soils can be considerably or highly contaminated with mercury. Eating them can provide to a consumer $\mathrm{Hg}$ at relatively high dose, while unresolved question is absorption rate of $\mathrm{Hg}$ compounds contained in ingested mushroom meal. Mercury is largely retained in flesh of culinary processed (blanched) mushrooms (Falandysz and Drewnowska 2015b), and this phenomenon seems to be more or less a species-specific feature, and if based on a dry matter content, no loss or even a pseudo-enrichment of $\mathrm{Hg}$ in a blanched mushrooms could be observed when compared to substrate product (unpublished, JF). Retention of $\mathrm{Hg}$ in blanched mushrooms implies on its occurrence in large portion in form of species hardly soluble in water ( $\mathrm{HgS}, \mathrm{HgSe})$, and this may suggest on limited absorption of $\mathrm{Hg}$ contained in a mushroom meal from the alimentary tract.

Acknowledgments Technical support by Eliza Lenz is acknowledged.

Open Access This article is distributed under the terms of the Creative Commons Attribution 4.0 International License (http:// creativecommons.org/licenses/by/4.0/), which permits unrestricted use, distribution, and reproduction in any medium, provided you give appropriate credit to the original author(s) and the source, provide a link to the Creative Commons license, and indicate if changes were made.

\section{References}

Allen RO, Steinnes E (1978) Concentrations of some potential toxic metals and other trace elements in wild mushrooms from Norway. Chemosphere 4:371-378
Árvay J, Tomáša J, Hauptvogl M, Kopernická M, Kováčik A, Bajčan D, Massányi P (2014) Contamination of wild-grown edible mushrooms by heavy metals in a former mercury-mining area. J Environ Sci Health B 49:815-827

Bargagli R, Baldi F (1984) Mercury and methyl mercury in higher fungi and their relation with substrata in a cinnabar mining area. Chemosphere 13:1059-1071

Borovička J, Řanda Z, Jelínek E, Kotrba P, Dunn CE (2007) Hyperaccumulation of silver by Amanita strobiliformis and related species of the section Lepidella. Mycol Res 111:1339-1344

Borovička J, Kotrba P, Gryndler M, Mihaljevič M, Řanda Z, Rohovec J, Cajthaml T, Stijve T, Dunn CE (2010) Bioaccumulation of silver in ectomycorrhizal and saprobic macrofungi from pristine and polluted areas. Sci Total Environ 408:2733-2744

Bressa G, Cima L, Costa P (1998) Bioaccumulation of Hg in the mushroom Pleurotus ostreatus. Ecotoxicol Environ Saf 16:85-89

Brzostowski A, Falandysz J, Jarzyńska G, Zhang D (2011a) Bioconcentration potential of metallic elements by Poison Pax (Paxillus involutus) mushroom. J Environ Sci Health A 46:378-393

Brzostowski A, Jarzyńska G, Kojta AK, Wydmańska D, Falandysz J (2011b) Variations in metal levels accumulated in Poison Pax (Paxillus involutus) mushroom collected at one site over four years. J Environ Sci Health A 46:581-588

Byrne AR, Tušek-Žnidarič M (1990) Studies of the uptake and binding of trace metals in fungi. Part I: accumulation and characterization of mercury and silver in the cultivated mushroom, Agaricus bisporus. Appl Organomet Chem 4:43-48

Byrne AR, Ravnik V, Kosta L (1976) Trace element concentrations in higher fungi. Sci Total Environ 6:65-78

Bystrzejewska-Piotrowska G, Pianka D, Bazała MA, Stębrowski R, Manjón JL, Urban PL (2008) Pilot study of bioaccumulation and distribution of cesium, potassium, sodium and calcium in king oyster mushroom (Pleurotus eryngii) grown under controlled conditions. Int J Phytoremediation 10:503-514

Cen F, Chen L, Hu Y, Xu H (2012) Chelator-induced bioextraction of heavy metals from artificially contaminated soil by mushroom (Coprinus comatus). Chem Ecol 28:267-280

Chojnacka A, Jarzyńska G, Drewnowska M, Nnorom IC, Falandysz J (2012) Yellow-cracking Boletes (Xerocomus subtomentosus) mushrooms: content and potential to sequestrate mercury. J Environ Sci Health A 47:2094-3011

Chudzyński K, Falandysz J (2008) Multivariate analysis of elements content of Larch Bolete (Suillus grevillei) mushroom. Chemosphere 73:1230-1239

Chudzyński K, Bielawski L, Falandysz J (2009) Mercury bioconcentration potential of Larch Bolete, Suillus grevillei, mushroom. Bull Environ Contam Toxicol 83:275-279

Cibulka J, Śiśak L, Pulkrab K, Miholova D, Szakova J, Fućikova A, Slamova A, Stehulova I, Barlakova S (1996) Cadmium, lead, mercury and caesium levels in wild mushrooms and forest berries from different localities of the Czech Republic. Sci Agric Biochem 27: $113-129$

Cocchi L, Vescovi L, Petrini L, Petrini O (2006) Heavy metals in edible mushrooms in Italy. Food Chem 98:277-284

Demirbaș A (2002) Metal ion uptake by mushrooms from natural and artificially enriched soils. Food Chem 78:89-93

Drewnowska M, Falandysz J (2015) Investigation on minerals composition and accumulation by popular edible mushroom Common Chanterelle (Cantharellus cibarius). Ecotoxicol Environ Saf 113: 9-17

Drewnowska M, Jarzyńska G, Kojta AK, Falandysz J (2012) Mercury in European Blusher, Amanita rubescens, mushroom and soil. Bioconcentration potential and intake assessment. J Environ Sci Health B 47:466-474

Drewnowska M, Lipka K, Jarzyńska G, Danisiewicz-Czupryńska D, Falandysz J (2013) Investigation on metallic elements of Fly 
Agaric, Amanita muscaria, fungus and the forest soils from the Mazurian Lakes District of Poland. Fresenius Environ Bull 22: 455-460

Drewnowska M, Nnorom IC, Falandysz J (2014) Mercury in the Tawny Grisette, Amanita vaginata Fr. and soil below the fruiting bodies. J Environ Sci Health B 49:521-526

Falandysz J (2002) Mercury in mushrooms and soil of the Tarnobrzeska Plain, southeastern Poland. J Environ Sci Health A 37:343-352

Falandysz J, Borovička J (2013) Macro and trace mineral constituents and radionuclides in mushrooms - health benefits and risks. Appl Microbiol Biotechnol 97:477-501

Falandysz J, Chwir A (1997) The concentrations and bioconcentration factors of mercury in mushrooms from the Mierzeja Wiślana sandbar, Northern Poland. Sci Total Environ 203:221-229

Falandysz J, Danisiewicz D (1995) Bioconcentration factors (BCF) of silver in wild Agaricus campestris. Bull Environ Contam Toxicol 55:122-129

Falandysz J, Drewnowska M (2015a) Macro and trace elements in Common Chanterelle (Cantharellus cibarius) mushroom from the European background areas in Poland: Composition, accumulation, dietary exposure and data review for species. J Environ Sci Health B 50:374-387

Falandysz J, Drewnowska M (2015b) Distribution of mercury in Amanita fulva (Schaeff.) Secr. mushrooms: accumulation, loss in cooking and dietary intake. Ecotoxicol Environ Saf 115:9-54

Falandysz J, Bona H, Danisiewicz D (1994) Silver uptake by Agaricus bisporus from an artificially enriched substrate. Z Lebensm- Unters Forsch 199:225-228

Falandysz J, Gucia M, Frankowska A, Kawano M, Skwarzec B (2001a) Total mercury in wild mushrooms and underlying soil substrate from the city of Umeå and its surroundings, Sweden. Bull Environ Contam Toxicol 67:763-770

Falandysz J, Szymczyk K, Ichihashi H, Bielawski L, Gucia M, Frankowska A, Yamasaki S (2001b) ICP/MS and ICP/AES elemental analysis (38 elements) of edible wild mushrooms growing in Poland. Food Addit Contam 18:503-513

Falandysz J, Bielawski L, Kannan K, Gucia M, Lipka K, Brzostowski A (2002a) Mercury in wild mushrooms and underlying soil substrate from the great lakes land in Poland. J Environ Monit 4:473-476

Falandysz J, Lipka K, Gucia M, Kawano M, Strumnik K, Kannan K (2002b) Accumulation factors of mercury in mushrooms from Zaborski Landscape Park, Poland. Environ Int 28:21-427

Falandysz J, Brzostowski A, Kawano M, Kannan K, Puzyn T, Lipka K (2003a) Concentrations of mercury in wild growing higher fungi and underlying substrate near Lake Wdzydze, Poland. Water Air Soil Pollut 148:127-137

Falandysz J, GuciaM BA, Kawano M, Bielawski L, Frankowska A, Wyrzykowska B (2003b) Content and bioconcentration of mercury in mushrooms from northern Poland. Food Addit Contam 20:247253

Falandysz J, Lipka K, Kawano M, Brzostowski A, Dadej M, Jędrusiak A, Puzyn T (2003c) Mercury content and its bioconcentration factors at Łukta and Morag, Northeastern Poland. J Agric Food Chem 51: $835-2836$

Falandysz J, Frankowska A, Jarzyńska G, Dryżałowska A, Kojta AK, Zhang D (2011) Survey on composition and bioconcentration potential of 12 metallic elements in King Bolete (Boletus edulis) mushroom that emerged at 11 spatially distant sites. J Environ Sci Health B 46:231-246

Falandysz J, Kojta AK, Jarzyńska G, Drewnowska A, Dryżałowska A, Wydmańska D, Kowalewska I, Wacko A, Szlosowska M, Kannan K, Szefer P (2012) Mercury in Bay Bolete Xerocomus badius: bioconcentration by fungus and assessment of element intake by humans eating fruiting bodies. Food Addit Contam A 29:951-961

Falandysz J, Dryżałowska A, Saba M, Wang J, Zhang D (2014a) Mercury in the fairy-ring of Gymnopus erythropus (Pers.) and Marasmius dryophilus (Bull.) P. Karst. mushrooms from the Gongga Mountain, Eastern Tibetan Plateau. Ecotoxicol Environ Saf 104: $18-22$

Falandysz J, Krasińska G, Pankavec S, Nnorom IC (2014b) Mercury in certain Boletus mushrooms from Poland and Belarus. J Environ Sci Health B 49:690-695

Falandysz J, Zhang J, Wang Y, Krasińska G, Kojta A, Saba M, Shen T, Li T, Liu H (2015a) Evaluation of the mercury contamination in mushrooms of genus Leccinum from two different regions of the world: accumulation, distribution and probable dietary intake. Sci Total Environ 537:470-478

Falandysz J, Zhang J, Wang Y, Saba M, Krasińska G, Wiejak A, Li T (2015b) Evaluation of the mercury contamination in Fungi Boletus species from latosols, lateritic red earths, and red and yellow earths in the Circum-Pacific Mercuriferous Belt of Southwestern China. PLoSONE 10(11):e0143608. doi:10.1371/journal.pone.0143608

Fischer RG, Rapsomanikis S, Andreae MO, Baldi F (1995) Bioaccumulation of methylmercury and transformation of inorganic mercury by macrofungi. Environ Sci Technol 29:993-999

Frankowska A, Ziółkowska J, Bielawski L, Falandysz J (2010) Profile and bioconcentration of minerals by King Bolete (Boletes edulis) from the Płocka Dale in Poland. Food Addit Contam B 3:1-6

Gadd GM, Rhee YJ, Stephenson K, Wie Z (2012) Geomycology: metals, actidines and biominerals. Environ Microbiol Rep 4:270-296

Galanda D, Mátel L, Strišovská J, Dulanská S (2014) Mycoremediation: the study of transfer factor for plutonium and americium uptake from the ground. J Radioanal Nucl Chem 299:1411-1416

Garciá MÁ, Alonso J, Melgar MJ (2005) Agaricus macrosporus as a potential bioremediation agent for substrates contaminated with heavy metals. J Chem Technol Biotechnol 80:325-330

Grgić J, Mandić M, Grgić Z, Manić Z (1992) Živa i arsen u samoniklim jestivim i nejestivim gljivama. Farm Glas 48:183-189

Gucia M, Jarzyńska G, Rafał E, Roszak M, Kojta AK, Osiej I, Falandysz J (2012a) Multivariate analysis of mineral constituents of edible Parasol Mushroom (Macrolepiota procera) and soils beneath fruiting bodies collected from Northern Poland. Environ Sci Pollut Res 19:416-431

Gucia M, Jarzyńska G, Kojta AK, Falandysz J (2012b) Temporal variability in twenty chemical elements content of Parasol Mushroom (Macrolepiota procera) collected from two sites over a few years. J Environ Sci Health B 47:81-88

$\mathrm{Hu}$ Y, Cheng H (2012) Mercury risk from fluorescent lamps in China: current status and future perspective. Environ Int 44:141-150

Jarzyńska G, Falandysz J (2011) The determination of mercury in mushrooms by CV-AAS and ICP-AES techniques. J Environ Sci Health A $46: 569-573$

Jarzyńska G, Chojnacka A, Dryżałowska A, Nnorom IC, Falandysz J (2012) Concentrations and bioconcentration factors of minerals by Yellow-cracking Bolete (Xerocomus subtomentosus) mushroom collected in Noteć Forest, Poland. J Food Sci 77:H202-H206

Jiang J, Qin C, Shu X, Chen R, Song H, Li Q, Xu H (2015) Effects of copper on induction of thiol-compounds and antioxidant enzymes by the fruiting body of Oudemansiella radicata. Ecotoxicol Environ Saf 111:60-65

Kojo M-R, Lodenius M (1989) Cadmium and mercury in macrofungimechanisms of transport and accumulation. Angew Bot 63:279-292

Kojta A, Jarzyńska G, Falandysz J (2012) Mineral composition and heavy metal accumulation capacity of Bay Bolete (Xerocomus badius) fruiting bodies collected near a former gold and copper mining area. J Geochem Explor 121:76-82

Kojta AK, Wang Y, Zhang J, Li T, Saba M, Falandysz J (2015) Mercury contamination of fungi genus Xerocomus in the Yunnan Province in China and the region of Europe. J Environ Sci Health A 50:1342-1350

Krasińska G, Falandysz J (2015a) Mercury in Hazel Bolete Leccinum griseum and soil substratum: distribution, bioconcentration and probable dietary exposure. J Environ Sci Health A 50:1259-1264 
Krasińska G, Falandysz J (2015b) Mercury in Orange Birch Bolete Leccinum versipelle and soil substratum: Bio-concentration by mushroom and probable dietary intake by consumers. Environ Sci Pollut Res. doi:10.1007/s11356-015-5331-8

Kubrová J, Zigovác A, Řanda Z, Rohovec J, Gryndler M, Krausová I, Dunn CE, Kotrba P, Borovička J (2014) On the possible role of macrofungi in the biogeochemical fate of uranium in polluted forest soils. J Hazard Mater 280:79-88

Kuusi T, Laaksovirta K, Liukkonen-Lilja H, Lodenius M, Piepponen S (1981) Lead, cadmium, and mercury contents of fungi in the Helsinki area and in unpolluted control areas. Z Lebensm Unters Forsch 173:261-267

Laaksovirta K, Lodenius M (1979) Mercury content of fungi in Helsinki. Ann Bot Fenn 16:208-212

Lassoe T, Del Conte A, Lincoff G (1996) The mushroom book. Kindersley Publishers, New York

Lepp NW, Harrison SCS, Morrell BG (1987) A role for Amanita muscaria $\mathrm{L}$. in the circulation of cadmium and vanadium in nonpolluted woodland. Environ Geochem Health 9:61-64

Liukkonen-Lilja H, Kuusi T, Laaksovirta K, Lodenius M, Piepponen S (1983) The effect of lead processing works on the lead, cadmium and mercury content of fungi. Z Lebensm- Unters -Forsch 176:120-123

Lodenius M, Kuusi T, Laaksovirta K, Liukkonen-Lilja H, Piepponen S (1981) Lead, cadmium and mercury contents of fungi in Mikkeli, SE Finland. Ann Bot Fennici 18:183-186

McGrath SP, Zhao F-J (2003) Phytoextraction of metals and metalloids from contaminated soils. Curr Oppin Biotechnol 14:277-280

Melgar MJ, Alonso J, Garcia MÁ (2009) Mercury in edible mushrooms and soil. Bioconcentration factors and toxicological risk. Sci Total Environ 407:5328-5334

Mleczek M, Siwulski M, Mikołajczak P, Gasiecka M, Sobieralski K, Szymańczyk M, Goliński P (2015) Content of selected elements in Boletus badius fruiting bodies growing in extremely polluted wastes. J Environ Sci Health A 50:767-775

Nasr M, Arp P (2011) Hg concentrations and accumulations in fungal fruiting bodies, as influenced by forest soil substrates and moss carpets. Appl Geochem 26:1905-1917

Nnorom IC, Jarzyńska G, Drewnowska M, Kojta AK, Pankavec S, Falandysz J (2013) Trace elements in sclerotium of Pleurotus tuber-regium (Ósu) mushroom-dietary intake and risk in Southeastern Nigeria. J Food Compos Anal 29:73-81

PIG, 2013 PIG. http://www.mapgeochem.pgi.gov.pl/poland/index.html

Quinche J (1976) La pollution mercurielle de diverses especes de champignons. Rev Suisse Agric 8:143-148

Quinche JP (1992) Les teneurs en huit éléments traces des carpophores de Coprinus comatus. Mycol Helv 5:133-142

Quinche JP, Dvorak V (1975) Le mercure dans des vegetaux et des sols de Suisse romande. Rech Agron Suisse 14:323-337

Rieder SR, Brunner I, Horvat M, Jacobs A, Frey B (2011) Accumulation of mercury and $m$ ethylmercury by mushrooms and earthworms from forest soils. Environ Pollut 159:2861-2869

Seeger R, Nützel R (1976) Quecksilbergehalt der Pilze. Z Lebensm Unters Forsch 160:303-312

Shen X, Yu S (2008) Analysis and assessment of heavy metal pollution in edible mushrooms from Guangdong (in Chinese). Acta Agriculturae Boreali-occidentalis Sinica 17:294-297

Stijve T, Roschnik R (1974) Mercury and methyl mercury content of different species of fungi. Travaux de chimie alimentaire et d'hygiène 65:209-220

Tel G, Çavdar H, Deveci E, Öztürk M, Duru E, Turkoğlub A (2014) Minerals and metals in mushroom species in Anatolia. Food Addit Contam B 7:226-231

Wang D, Chen L, Jing X, Xu H (2012) Chelator- and surfactant-assisted remediation of heavy metal contaminated soil by Tricholoma lobayense Heim. Chin J Appl Environ Biol 18:100-107

Wiejak A, Wang Y, Zhang J, Falandysz J (2014) Bioconcentration potential and contamination with mercury of pantropical mushroom Macrocybe gigantea. J Environ Sci Health B 49:811-814

Xu J, Garcia Bravo A, Lagerkvist A, Bertilsson S, Sjöblom R, Kumpiene $\mathrm{J}$ (2015) Sources and remediation techniques for mercury contaminated soil. Environ Int 74:42-53

Zhang W, Hu Y, Cao Y, Huang F, Xu H (2012) Tolerance of lead by the fruiting body of Oudemansiella radicata. Chemosphere 88:467475

Zhang J, Li T, Yang Y-L, Liu H-G, Wang Y-Z (2015) Arsenic concentrations and associated health risks in Laccaria mushrooms from Yunnan (SW China). Biol Trace Elem Res 164:261-266 